\title{
Patient-perceived factors contributing to low tuberculosis cure rate at Greater Giyani healthcare facilities
}

\begin{tabular}{|c|c|}
\hline $\begin{array}{l}\text { Authors: } \\
\text { Nandzumuni } \\
\text { Rachel T. Lebe } \\
\text { Ntsieni S. Mas } \\
\text { Lunic B. Khoza }\end{array}$ & $\begin{array}{l}\text { Maswanganyi }{ }^{1} \\
\mathrm{e}^{2} \\
\mathrm{nu}^{2}\end{array}$ \\
\hline $\begin{array}{l}\text { Affiliations: } \\
{ }^{1} \text { Limpopo Dep } \\
\text { Health, Mopar } \\
\text { Directorate, } \mathrm{Sc}\end{array}$ & $\begin{array}{l}\text { artment of } \\
\text { i District TB } \\
\text { uth Africa }\end{array}$ \\
\hline \multicolumn{2}{|c|}{$\begin{array}{l}{ }^{2} \text { Department of Advanced } \\
\text { Nursing, University of Venda, } \\
\text { South Africa }\end{array}$} \\
\hline \multicolumn{2}{|c|}{$\begin{array}{l}\text { Correspondence to: } \\
\text { Rachel T. Lebese }\end{array}$} \\
\hline \multicolumn{2}{|c|}{$\begin{array}{l}\text { Email: } \\
\text { rachel.lebese@univen.ac.za }\end{array}$} \\
\hline \multicolumn{2}{|c|}{$\begin{array}{l}\text { Postal address: } \\
\text { Private Bag X5050, } \\
\text { Thohoyandou 0950, } \\
\text { South Africa }\end{array}$} \\
\hline \multicolumn{2}{|c|}{$\begin{array}{l}\text { Received: } 01 \text { Feb. } 2013 \\
\text { Accepted: } 29 \text { Nov. } 2013 \\
\text { Published: } 03 \text { Apr. } 2014\end{array}$} \\
\hline \multicolumn{2}{|c|}{$\begin{array}{l}\text { How to cite this article: } \\
\text { Maswanganyi, N.V., Lebese, } \\
\text { R.T., Mashau, N.S. \& Khoza, } \\
\text { L.B., 2014, 'Patient-perceived } \\
\text { factors contributing to } \\
\text { low tuberculosis cure } \\
\text { rate at Greater Giyani } \\
\text { healthcare facilities', Health } \\
\text { SA Gesondheid 19(1), Art. } \\
\text { \#724, } 8 \text { pages. http://dx.doi. } \\
\text { org/10.4102/hsag.v19i1.724 }\end{array}$} \\
\hline \multicolumn{2}{|c|}{$\begin{array}{l}\text { (c) 2014. The Authors } \\
\text { Licensee: AOSIS } \\
\text { OpenJournals. This } \\
\text { is licensed under the } \\
\text { Creative Commons } \\
\text { Attribution License. }\end{array}$} \\
\hline Read online & \\
\hline 口istar & $\begin{array}{l}\text { Scan this QR } \\
\text { code with your } \\
\text { smart phone or } \\
\text { mobile device } \\
\text { to read online. }\end{array}$ \\
\hline
\end{tabular}

Authors:

Maswanganyi ${ }^{1}$

\section{Affiliations:}

th, Mopani District TB

${ }^{2}$ Department of Advanced

Nursing, University of Venda,

Correspondence to:

Rachel T. Lebese

Email:

Postal address:

Thohoyandou 0950

Dates:

Accepted: 29 Nov. 2013

How to cite this article:

Maswanganyi, N.V., Lebese,

factors contributing to

low tuberculosis cure

Copyright:

is licensed under the

Creative Common

Attribution License.
Background: Compliance with tuberculosis (TB) treatment is unpredictable. Most patients do not comply because they do not see the importance of doing so, which is usually influenced by lack of knowledge.

Objectives: The purpose of the study was to explore and describe the factors contributing to low TB cure rates in Greater Giyani Municipality, as viewed by patients.

Method: The study was conducted in the Greater Giyani Municipality in Limpopo Province which had a TB cure rate ranging from $14 \%$ to $94 \%$. The research design in this study was qualitative, exploratory, descriptive and contextual in nature. The population consisted of all TB patients diagnosed and referred for treatment and care in Primary Health Care (PHC) facilities. Non-probability purposive sampling was used to select TB patients and health facilities which had a cure rate lower than the national target of $85 \%$. One patient was sampled from each PHC facility. An in-depth face-to-face interview was used to collect data using an interview guide.

Results: The findings showed that most of the TB patients come from poor families, which makes it difficult for them to obtain financial and food security. The health facilities often run out of food supplements and TB medicine. Cultural beliefs about TB also lead to TB patients seeking assistance from traditional health practitioners and faith-based healers.

Conclusion: There is a need to have a policy regarding how discharged tuberculosis patients on treatment are supervised when at home. Healthcare facilities should also ensure that there is enough medication for these patients as lack of medication can lead them to default.

Agtergrond: Dit is onmoontlik om te bepaal of pasiënte by hulle tuberkulosebehandeling gaan hou. Die meeste pasiënte hou nie daarby nie omdat hulle nie die belangrikheid daarvan insien nie.

Doelwitte: Die doel van die studie was om die faktore wat in die Groter Giyani Munisipaliteit tot lae genesingskoerse onder TB-pasiënte lei, te ondersoek en te beskryf, soos deur pasiënte gesien.

Metode: Die studie is in die Groter Giyani Munisipaliteit in die Limpopo Provinsie gehou, waar die genesingskoers vir TB tussen $14 \%$ en $94 \%$ is. Die navorsing in hierdie studie was kwalitatief, verkennend, beskrywend en kontekstueel van aard. Die populasie het bestaan uit alle gediagnoseerde TB-pasiënte wat vir behandeling en sorg na primêre gesondheidsorgfasiliteite verwys is. Nie-waarskynlikheid, doelgerigte steekproefneming is gebruik om TB-pasiënte en gesondheidsfasiliteite te kies wat 'n laer genesingskoers as die nasionale doelwit van $85 \%$ het. Een pasiënt uit elke primêre gesondheidsorgfasiliteit is by die steekproef ingesluit. ' $n$ Diepgaande persoonlike onderhoud is gebruik om data met behulp van 'n onderhoudgids in te samel.

Resultate: Die bevindinge toon dat die meeste van die TB-pasiënte uit arm gesinne kom, wat dit vir hulle moeilik maak om finansiële en voedselsekerheid te hê. Die gesondheidsfasiliteite se voedselaanvullings en TB-medisyne raak dikwels op. Kulturele oortuigings oor TB lei ook daartoe dat TB-pasiënte by tradisionele gesondheidsorgpraktisyns en geloofsgebaseerde genesers hulp soek.

Gevolgtrekking: Dit is nodig dat 'n beleid oor toesig oor die behandeling van ontslaande TB-pasiënte wat tuis aansterk, opgestel word. Gesondheidsorgfasiliteite behoort ook seker te maak dat daar genoeg medisyne vir hierdie pasiënte is, aangesien 'n gebrek aan medisyne daartoe kan lei dat die pasiënte ophou om hulle medikasie te gebruik. 


\section{Introduction}

Compliance with tuberculosis (TB) treatment is unpredictable. One can never tell which patients will adhere to treatment or which patients might not have sufficient knowledge regarding how to take their treatment. Most TB patients do not comply because they do not see the importance of doing so. It can also be assumed that the low TB cure rate in the study area could be influenced by the same reasons as it is a predominantly rural area with high unemployment and illiteracy rates.

A study conducted in Addis Ababa, Ethiopia, by Sagbakken, Frich and Bjune (2008), revealed that lengthy anti-TB treatment exhausted both the patients' and their relatives' financial and practical support systems. Because of a lengthy anti-TB treatment period and its effect on support systems, patient often do not adhere to the treatment. Meanwhile, a study conducted in China by Tang and Squire (2005) also revealed that patients in rural areas experienced difficulties in reaching treatment points because they could not afford to pay for their daily transport. Transport costs were found to affect treatment adherence because patients could not afford to go to collect their medication at health centres (Tang \& Squire ibid). In China, it was also noted that where TB services were not provided for free, patients did not adhere to treatment because they were expected to pay every time they visited the health facility (Tang \& Squire ibid). It was therefore assumed that, given the economic status of the patients in these rural areas, financial insecurity could also be a contributory factor for non-adherence to treatment.

A study in rural North Ethiopia by Demissie, Getahon and Lindjtørn (2003) revealed that lack of support amongst TB patients is a barrier to their being cured. The study findings further revealed that TB patients who belonged to a support group showed a high TB cure rate $(68.7 \%)$ compared with those who did not belong to any support group. In the same study, it was also found that patients prefer to have DOTS supporters in their local communities rather than at the healthcare facility. This was also confirmed by a study conducted in Namibia by Zvavamwe and Ehlers (2008), which showed that Directly-Observed Treatment, Shortcourse (DOTS) has increased the cure rate in most of the facilities. This is evidenced by the initiative on the part of the Department of Health (DoH) in South Africa, wherein a teamwork approach to TB treatment and management is recommended. The belief is that joint responsibility between healthcare personnel, TB patients and the community will provide the necessary support, in order for TB patients to complete their treatment. The teamwork approach should outline clearly the responsibilities of each team member. In addition, families should be involved in the treatment plan of TB patients so that they can support the patient during the course of treatment (DoH 2009b). Despite the existence of this initiative in South Africa, the cure rate in most facilities, including Greater Giyani, is still low.

Research shows that the movement of patients from one area to another is next is another factor that contributes to non-adherence. This is supported by the study conducted in
China by Tang and Squire (2005), which showed that most TB patients move from one place to another without reporting to a treatment supporter. As a result, treatment is interrupted, as lack of support might influence negative actions. The study further revealed that TB patients who do not register with local TB dispensaries failed to complete standardised treatments. Amongst those TB patients registered and treated by $\mathrm{TB}$ dispensaries, only $61 \%$ received the recommended standardised anti-TB treatment, whilst only $21 \%$ of the TB patients treated by the general hospitals received the recommended treatment (Tang \& Squire ibid). However, there were difficulties in handling the increased number of TB patients, most of whom were rural migrants working in the urban areas. The municipal TB control centres faced a challenge with regard to treating and monitoring these patients because of their transient nature (Tang \& Squire ibid). This might also be a factor contributing to low cure rates in Greater Giyani, as most people move to urbanised areas and farms for work.

Although TB services are provided for free at government institutions in Uganda, the study conducted by Kiwuwa, Karamagi and Mayanja (2005) showed that people still present themselves to private clinics because of poor quality services in government institutions. Patients diagnosed in private clinics are referred to local health institutions because of the high costs of the services, which most TB patients cannot afford. TB treatment lasts for six months. As a result of underfunding for TB services, patients with persistent symptoms are also referred to higher levels of care because of a lack of proper equipment. The movement of patients from one health institution to another resulted in patients failing to complete their medication because they felt discouraged (Kiwuwa et al. ibid). Only a few patients can afford to go to private intuitions, but public institutions are regarded as offering poor services. Therefore, referrals may cause patients to default; hence the low cure rate.

The stigma attached to the disease, TB, is also believed to prevent TB patients from seeking immediate medical attention. A study conducted in China by Tang and Squire (2005) revealed that people diagnosed with TB were afraid of being known in the community as having the disease. This affected mostly women and rural migrants. Women were afraid that their husbands would divorce them for fear of themselves and their children becoming infected. Rural migrants were also afraid of losing their jobs. The cure rate was affected because patients preferred to take treatment on their own, without the knowledge of even family members. As a result, they did not get much support (Tang \& Squire ibid). Lack of support and taking treatment privately often led to patients forgetting to take their treatment, leading to nonadherence. Support has been identified as being successful in making patients adhere to treatment, especially through DOTS. This might mean that patients are likely to default treatment because of a failure to disclose their condition to friends and relatives because of a fear of being stigmatised.

In South Africa, a study conducted in the Eastern Cape by Cramm et al. (2010) found that the associated stigma might influence TB patients' behaviour in seeking help and 
adhering to TB treatment. In the same study, the findings showed that people infected with TB had a tendency to hide their TB status out of fear of being stigmatised. This might be influenced by its association with HIV infection.

Lack of knowledge about TB causes patients to become frustrated and depressed as if by lacking the necessary knowledge, they cannot make an informed decision about their own health. In order to address this problem, the $\mathrm{DoH}$ in South Africa recommended that a comprehensive Advocacy, Communication and Social Mobilisation (ACSM) plan be developed and implemented. The plan both promotes and urges the involvement of political leaders in the mobilisation of resources (DoH 2009a). The plan also encourages the spread of knowledge and awareness of TB to the community at large. With this approach it is hoped that treatment adherence and case detection will improve. The plan describes how ACSM can assist in dealing with stigma and discrimination. It further recommends that the Patient's Charter for TB care be communicated to TB patients and their families, so that they become knowledgeable about their rights and responsibilities (DoH 2009a).

Proper communication between the health worker and the patient is vital in order for patients to understand their condition and its treatment. A study conducted in Senegal by Hane et al. (2007) affirmed that there was no proper communication between patients and healthcare providers regarding diagnosis, registration and during continuity of treatment. Another study also found that patients were not given enough information about $\mathrm{TB}$, which resulted in their defaulting on their treatment protocol (Hane et al. ibid). The study found that patients believed that after two months of treatment they would be cured, as they felt better. In other words, patients did not have sufficient knowledge to discern that the importance of completing treatment is the same as taking the full course of treatment. Findings from the same study also revealed that short messages given to TB patients by healthcare workers strengthened the issue of stigma around TB. The study further recommended that all TB patients be given information on the spread and prevention of $\mathrm{TB}$, emphasising that counselling be provided to TB patients (Hane et al. ibid). Communication is therefore vital for proper treatment management and follow up. The low literacy levels and staff shortages in rural settings might also hinder proper and efficient information regarding the discharge of TB patients, which could be contributing to poor treatment follow ups and, consequently, defaulting on treatment.

A study conducted by Hoa et al. in Vietnam (2003) concluded that patients' beliefs had a negative impact on the cure rate. In particular, patients believed that TB was inherited or caused by hard work and deep thinking. TB patients believed that there was an alternative treatment to cure the disease, depending on what caused it, rather than utilising health institutions for their treatment. TB patients also visited traditional health practitioners and faith healers because they did not know that the treatment provided by the health facilities was actually the only cure for TB (Van der Werf, Dade \& Van der Mark 1990). This study was conducted in the rural areas with strong cultural beliefs which could have attributed to the low cure rate that is experienced in primary healthcare (PHC) facilities.

A study conducted by Ai et al. (2010) in Shaanxi, China, revealed that patients who experienced side effects did not continue taking their TB treatment. This is because of the cost related to the treatment of the side effects. Moreover, patients who did not continue with treatment because of side effects did not know that they would experience such effects and that they were not supposed to stop taking their treatment (Ai et al. ibid). This affirms the study by Hane et al. (2007) which revealed that communication is vital in ensuring treatment compliance by patients.

A study conducted in rural Kwazulu-Natal in South Africa by Gandhi et al. (2005) showed that the presence of diseases such as HIV and multi-drug resistant TB (MDR-TB) affected the cure rates negatively because most of the patients died. The results showed further that the development of MDR-TB in patients had a negative impact on cure rates.

The study conducted by Kiwuwa et al. (2005) in Kampala, Uganda, found that a delay in diagnosis and initiation of treatment contributed to low TB cure rates well below the national target of $85 \%$. Interestingly, smokers often delayed seeking medical assistance because they associate coughing with their smoking and not with TB. The same study also asserted that alcoholics and subsistence farmers also delayed visiting health facilities because of a lack of knowledge about signs and symptoms. Increased death rates were noted, instead of an increased number of cures (Kiwuwa et al. ibid).

\section{Problem statement}

The major unresolved challenge in the management of $\mathrm{TB}$ is treatment completion, which results in high death rates and the occurrence of drug-resistant TB (World Health Organization [WHO] 2010). The implementation of DOTS in South Africa (SA) was to ensure compliance with treatment by TB patients and thus increase cure rates. According to the WHO (WHO 2009b), the implementation of DOTS in South Africa was $100 \%$. In Limpopo Province, DOTS coverage ranges between $75 \%$ and $80 \%$ and coverage in Mopani District was $94 \%$. However, this did not have an impact on the TB cure rate, which was less than the national target of $85 \%$. In 2008, Limpopo Province had a TB cure rate of $65 \%$ and a defaulter rate of $7 \%$, whilst Mopani District had a TB cure rate of $68.4 \%$. In the Greater Giyani Municipality, the TB cure rate for 2008 was $70.2 \%$ - still far below the national target of $85 \%$ (Garrib et al. 2008). This study thus sought to explore and describe the factors which contribute to the low TB cure rate at PHC facilities within the Greater Giyani Municipality, as viewed by TB patients.

\section{Research objectives}

The objective of this study was to identify the factors that contribute to low TB cure rates in the Greater Giyani Municipality, as viewed by TB patients. 


\section{Contribution to the field}

Identification of factors contributing to low TB cure rates will assist primary healthcare nurses in developing strategies to address these factors. The health education lessons in the primary health care facilities would be structured to address negative factors identified. The outcome of this study could influence policy in relation to management of discharged patients on TB treatment. The study could open new avenues for further research.

\section{Research methods and design}

A qualitative, explorative, descriptive and contextual design was used for this study.

Views about the factors contributing to low TB cure rates were sought from patients and described by the researcher. The researcher chose descriptive research because it summarised the findings concerning the problem being investigated (Burns \& Grove 2001; Creswell 2003; Polit \& Beck 2007). In this study, the researcher used a qualitative research design, which is a systematic and subjective approach, in order to explore and describe the factors contributing to low TB cure rates from the patients' point of view. Conversations with participants were recorded and field notes were used to document non-verbal cues. A voice recorder was used to record what the participants were saying, so as to help the researcher remember what was said during the conversation (Burns \& Grove ibid). Participants were interviewed in their own setting, namely their homes, using their mother tongue. Patients were allowed to express their views in relation to factors that influence TB cure rates. Probing and paraphrasing were used in order to avoid influencing their responses.

\section{Population and sampling}

In this study, the population comprised all TB patients who were diagnosed with $\mathrm{TB}$ at the hospital and transferred to the PHC facilities for continuity of care. These were patients who had been discharged from the hospital and were continuing treatment at home under the supervision of the PHC.

Non-probability purposive sampling was used to select both participants and PHC facilities. Facilities with low TB cure rates were selected for inclusion in the study. Discharged TB patients who were still taking treatment at home and being supervised at the selected PHC facility were selected purposively.

\section{Data collection}

The data-gathering method of choice was an individual faceto-face interview supported by an interview guide (Creswell 2003). The researcher asked the participants questions in order to stimulate their thoughts. Probing and follow-up questions were asked as a follow up to the participants' responses. The following questions were included in the interview guide:

- 'Can you tell me, in your view, what could be the factors that make patients not be completely cured of TB?'
- 'What are the challenges encountered by patients that make them fail to be completely cured of TB?'

The duration of the individual interviews was dependent upon the way in which the participants responded to probing questions.

\section{Data analysis}

The researcher used qualitative data analysis methods to analyse the data. The Tech's open coding method of data analysis was used to guide the researcher in this study (De Vos 2005). All data were read carefully in order to obtain a deeper understanding and sense of the whole. Ideas were written down as they came to mind. The researcher selected one case and asked what it was about, thinking about the underlying meaning of the information gathered. The researcher's thoughts were then written in the margin. A list was made of all themes and similar themes were clustered together. The researcher applied the list of themes to the data. The themes, abbreviated as codes, were then written next to the appropriate segments of the transcripts, whereafter subthemes were developed (De Vos ibid). Data saturation was reached after 12 participants had been interviewed. Literature control was conducted by comparing the data with existing research, which allowed the findings of the research study to be contextualised within general scientific knowledge without that knowledge exerting any undue influence on the findings (Creswell 2003).

\section{Ethical considerations}

Ethical approval to conduct the study was obtained from the Ethics Committee of the University of Venda (SHS/11/PH/ EO811). Permission was also obtained from the Limpopo Provincial Department of Health. The ethical standards regarding privacy, anonymity and confidentiality, as set by the Democratic Nursing Organisation of South Africa (DENOSA), were adhered to both before and during the structured data collection (Hassim, Heywood \& Berger 1998). All information shared by the patients was kept confidential. Informed consent was signed, each patient was interviewed in their home alone and code names were used to conceal their identity.

\section{Trustworthiness}

Four principles were applied in order to ensure trustworthiness. These strategies are credibility, dependability, conformability and transferability (Brink, Van der Walt \& Van Rensburg 2012). Activities to ensure credibility included member checking, where information was presented to experts for advice, prolonged engagement by using face-to-face interviews, probing and paraphrasing and reflexivity by keeping a journal of all activities. Transferability was obtained by using a purposeful sampling method, working contextually and by creating a dense description of the methodology.

\section{Results and discussion}

The 12 participants were TB patients -3 men and 9 women, with ages ranging from 25 to 57 . Eight of the TB patients 
were permanently-employed farmworkers and were breadwinners. Their salary ranged between R600 and R1200 per month. The other four participants depended on their parents' old-age grants and child grants. The following themes were identified from the TB patients' views in relation to factors contributing to low TB cure rates.

TB patients experience side effects and they do not have sufficient knowledge regarding these side effects. They also experience a shortage of TB medication from the health facilities. Shortage of food, long duration of TB treatment and transport constraints are other challenges for these patients.

\section{Side effects of tuberculosis treatment}

During the interviews, the TB patients related their experiences concerning the taking of TB treatment. They mentioned that they experience some side effects from the treatment, manifested as nausea and vomiting. Patients said that they do not always take their treatment regularly because of that experience. It was found that some of the TB patients believe that the treatment worsens their condition. They also mentioned that they do not report these side effects to health professionals, but rather continue collecting their medication, to give the nurses the impression that they are treatment-compliant. It was also found that side effects inconvenienced the participants during the performance of their daily activities, as they were also expected to do some household activities.

One participant said:

'Eeey! I become very sick when I take the TB tablets. Then I decided not to take them anymore, but I went there to collect treatment on a monthly basis to give the nurses the impression that I was complying. Yoo!! Those pills make me very sick.' (P6, Male, 44)

Another participant said:

'I can't even walk a short distance after taking treatment because it makes me feel dizzy. That is why I tell that person who comes to my home that I don't want to take this treatment daily. This is affecting my daily routine because I must also do some household chores.' (P2, Female, 27)

The influence of side effects on patients' adherence to treatment was also identified in the literature, where TB patients were found to fail to complete their treatment course because they experience side effects, the treatment of which side effects was found to be very expensive (Ai et al. 2010). The participants had an income of R600 - R1200, which affected the ability to afford treatment of the side effects.

However, another barrier that was identified by Selig et al. (2003) was the negative attitude of healthcare professionals toward TB patients. This led to non-adherence with treatment. It was also found that some patients did not comply with TB treatment because of the side effects which were not explained to them (Wares et al. 2003). Ai et al. (2010) found that patients who experienced side effects did not continue taking their TB treatment because of the costs associated with the treatment of side effects. It was found that patients who did not continue with treatment because of side effects did not know that they would experience such effects and that they were not supposed to stop taking their treatment (Ai et al. ibid). Lack of information provided by professionals therefore has a negative impact, as patients can only react positively to side effects if they are knowledgeable about such and how to deal with them.

From their responses it is clear that TB patients experience side effects which make them believe that the TB treatment is worsening their condition. This could mean that TB patients should be given medication to curb the side effects together with their TB treatment. Nurses should not to wait until patients experience side effects because they then lose faith in the TB treatment itself. It is also necessary for nurses to always refer to the TB guidelines when managing TB patients.

\section{Shortage of tuberculosis treatment at primary healthcare facilities}

During the interviews, the TB patients mentioned their experiences regarding the shortage of TB treatment at $\mathrm{PHC}$ facilities as being one of the barriers to treatment adherence.

The patients indicated that they sometimes resort to using medication from traditional health practitioners because when they go there, they always get treatment. They also complained about the difficulty in reaching the hospitals, where some patients collect their treatment when there is a shortage at their local PHC facilities. They indicated that they need to use public transport and said that they get tired of visiting the health facilities when they are not sure of the exact date when treatment will be available.

One participant said:

'When there is no treatment at the health facility I go to the traditional health practitioner to get treatment so that I can have something to use in the meantime. However when treatment is available I go and collect it then start using it again. Hey [laughing], my traditional health practitioners always have medication for me because they know that people can come any time for assistance.' (P12, Female, 32)

Another participant said:

'We sometimes get tired of visiting the facility because there is no treatment and they don't tell us when it will be available. We go to check on a daily basis. Those with some cash are referred to the hospital to collect treatment. But some of us have to wait for the treatment to be brought to the local health facility.' (P10, Male, 52)

The literature indicates that inadequate drug supply and poor management pose a risk of creating home-grown drug resistance in TB patients (DoH 2009). In a study conducted in Russia by Dimitrova et al. (2006), it was found that lack of treatment was a barrier to treatment adherence. It was further revealed that TB patients do not always present for treatment and there were no vehicles available to track 
and trace them. The study also revealed that staff shortages contributed to poor treatment adherence because TB patients were not attended to speedily when they went to the treatment facilities. It was also noted that when patients go to the health service for treatment and do not receive it, it is difficult for them to go back again. This is also worsened by the fact that these patients' financial status is poor. Transport and distance to the health services might be other factors as most of the participants stay quite a distance from the health services.

A study conducted in UK by the UK Coalition to Stop TB (Capstick, Laycock \& Lipman 2011) reported that 63\% of the 77 treatment centres reported difficulties in obtaining antiTB drugs. This resulted in $27 \%$ of TB patients interrupting treatment and $19 \%$ having to alter the types of drugs used. It was also revealed that the centres treating MDR-TB also experienced such difficulties, which resulted in $16 \%$ of patients interrupting treatment and 5\% having to alter the types of drugs used.

It has been noted from the previous discussion that there is sometimes a shortage of $\mathrm{TB}$ treatment in the primary healthcare facilities, meaning that patients coming for treatment sometimes don't receive it. This was identified as being one of the factors making patients non-compliant, contributing to the low cure rate. To overcome this problem, health facilities should determine the number of patients on TB treatment and make provision for 10\% extra stock, according to TB guidelines ( $\mathrm{DoH} 2009$ ).

\section{Shortage of food during the course of treatment}

During the interviews, TB patients described how a shortage of food affects their adherence to treatment. They said that it is difficult for them to take treatment on an empty stomach because they experience abdominal pains after doing so. Consequently, this makes them stop taking their treatment.

The data indicate that most TB patients live in poverty, with little or nothing to eat. Most of them said that they are assisted by treatment supporters, who sometimes give them food to eat before giving them their treatment. They also said that they receive food parcels from the social worker whenever they are available. However, they indicated that when there is nothing to eat, they take their treatment on an empty stomach, eventually experiencing abdominal pains.

One participant said:

'I don't have any money to buy food because I am the breadwinner who sometimes got some part-time jobs so that I can support my family. Now I am sick and I don't have the energy to look around for a job.' (P5, Male, 31)

Another participant said:

'Sometimes they refer us to the social worker who gives us some food parcels. But sometimes there is nothing and when I take treatment on an empty stomach I experience abdominal pains. I often go away when I see a treatment supporter coming because
I know I will be forced to take treatment even if I have not had anything to eat.' (P8, Female, 56)

One participant said:

'The treatment supporter sometimes comes with her own food to give me so that I can have something to eat before taking treatment. I once dropped out from taking this treatment and went to Johannesburg to look for a job because I had nothing to eat.' (P6, Male, 44)

The literature indicates that social support also has a positive influence on TB patients, making them adhere to treatment, thus getting cured in the process (Walley et al. 2001). The research results of this study also confirm the findings of the previous authors in relation to availability of food and adherence to TB treatment, as well as the presence of a DOTS supporter and adherence to TB treatment. It was also found that TB patients who complied with treatment were those who were given food parcels during their treatment period. Mabunda and Bradley (2011) also stated that lack of food was reported to be the main stumbling block for treatment adherence because one cannot take treatment on an empty stomach.

From the data, it is clear that lack of food is also a barrier to treatment adherence because TB patients avoid taking treatment on an empty stomach. This means it is important to encourage TB patients to start community projects so that they can get money to buy food. It might also mean that interdepartmental collaboration is needed, such as liaising with the Department of Agriculture for assistance with those projects.

During the interviews with the TB patients, it was revealed that prolonged taking of TB treatment affects the patients' adherence because it affects their daily routine activities. The data indicated that this causes challenges for the TB patients and their families because it exhausts them financially. They also said that they also become tired of taking the treatment for such a long period of time. In addition, they said that they had transport challenges when they needed to access the health facilities because of shortage of funds.

\section{One participant said:}

'This TB treatment is like you are being punished because you are supposed to stay at home until someone gives you the treatment. It means you should drop all your other plans for months and concentrate on this treatment.' (P7, Female, 54)

\section{Another participant said:}

'I sometimes feel so weak and frustrated that I cannot reach the facility and when I ask for assistance with transport funds, no one helps you. Everyone complains that the treatment is taking too long to complete. They complain and say they also have their own family needs.' (P11, Female, 33)

Literature indicates that TB patients experience treatment shortage from the facilities, which affects their adherence. TB patients said that they experience problems concerning 
shortage of funds for transport because they are too weak to reach the facility on foot (Van Der Werf et al. 1990). Participants indicated that these problems make it difficult for them to take TB treatment because they are unemployed and their relatives get tired of giving them financial support.

The results showed that patients in rural areas experienced difficulties in reaching treatment points because they could not afford to pay for their daily transport costs. Transport costs were found to affect treatment adherence because patients could not travel to collect their treatment. It was also found that this disrupts their daily activities, because whenever they leave they have to remember the treatment intervals and, in addition, the duration of treatment is very long. The lengthy period of TB treatment courses exhausts the TB patients and their families both financially and emotionally, resulting in non-adherence to treatment (Sagbakken, Frich \& Bjune 2008).

From the TB patients' responses, it was noted that taking treatment for 6 or 8 months causes strain on them and also their families because sometimes their family members get tired of giving TB patients the emotional and financial support that they need. This might indicate that the TB treatment protocol needs to be reviewed so that the treatment time is reduced. It is also important to include family members and relatives in the management plan of the patient so that they understand what is expected during the treatment period.

\section{Long duration of tuberculosis treatment and transport constraints}

During interviews, TB patients said that the long duration of the TB course affects treatment adherence because it affects the patients' daily activities.

Data indicated that the long period of TB treatment causes challenges to both the TB patients and their relatives because it exhausts them financially. They also said that they become tired of taking the treatment for such a long period of time and said that they experience a challenge with regard to transport to health facilities because of a shortage of funds.

One participant said:

'This TB treatment is like you are being punished because you are supposed to stay at home until someone delivers the treatment to you. It means that you should drop all your plans for months and concentrate on this treatment.' (P9, Female, 29)

Another participant said:

'I sometimes feel so weak and frustrated that I cannot reach the facility, and when I ask for assistance with transport funds you find that no one gives you. Everyone is complaining that it is taking so long for me to complete the TB course. They tell me that there is no money anymore because they have to look at other family needs.' (P3, Female, 47)

The literature indicates that TB patients experience difficulties in reaching the health facilities to collect treatment because of a shortage of funds available for transport. In addition, they are too weak to walk to the facility (Van der Werf et al.
1990). The participants indicated that these problems make it difficult for them to complete the TB treatment because they are unemployed and their families get tired of giving them financial support.

The study also showed that patients in rural areas experienced difficulties in reaching health facilities because they could not afford their daily transport costs. In other words, transport costs affected treatment adherence because they did not have money to go to collect their TB treatment. The study also showed that this disrupts their daily activities because whenever they go there, they have to take note of the next treatment time and plan accordingly. The lengthy period of the treatment course also exhausted the patients and their relatives both financially and emotionally, resulting in nonadherence to treatment (Sagbakken, Frich \& Bjune 2008).

Financial constraints also became evident in the study conducted by Sukumani, Lebese and Khoza (2011), where it was shown that TB patients run out of funds when they have to travel long distances to collect treatment at health facilities. This is because the fares for taxis are too high. It was also revealed in this study that family members get exhausted physically and psychologically because of the support that they are expected to give to TB patients for the duration of their treatment.

\section{Limitations of the study}

The limitation in this study was that only TB patients from one municipality, namely, Mopani District, participated, but family members of the TB patients were not included.

\section{Recommendations}

It is recommended that TB patients be counselled when diagnosed so that they understand their diagnosis, treatment regime and responsibilities. The study showed that most of the TB patients came from poor families, which makes it difficult for them to get financial and food security. In addition, the health facilities often run out of food supplements and TB drugs. It was also noted that there is a poor referral system for TB patients from hospitals to PHC facilities. It is therefore recommended that PHC nurses and hospital staff members dealing with TB patients should design the lines of communication related to management of TB patients. Regular meetings are also encouraged between the two parties in order to share information and address problems at an earlier stage.

\section{Conclusion}

Tuberculosis treatment management still poses a problem to the success of obtaining acceptable cure rates in the country. Patients' level of understanding, poor supervision and poor management of treatment stock were found to be some of the factors contributing to low cure rate. Policies need to be developed for the proper management of discharged TB patients on treatment. 


\section{Acknowledgements Competing interests}

The authors declare that they have no financial or personal relationship(s) which may have inappropriately influenced them in writing this article.

\section{Authors' contributions}

N.V.M. (Limpopo Department of Health) was responsible for the research proposal, as well as data collection and analysis and writing up of the manuscript; R.T.L. (University of Venda) contributed to the data collection and analysis and also the conceptualisation of the manuscript; N.S.M. (University of Venda) contributed to the data collection and analysis, as well as refining the methodology; and L.B.K. (University of Venda) was involved in data, analysis, conceptualisation and critical reading of the manuscript.

\section{References}

Ai, X., Men, K., Guo, L., Zhang, T., Zhao, Y., Sun, X., et al. 2010, 'Factors associated with low cure rate of tuberculosis in remote poor areas of Shaanxi, China: A case control study', BMC Public Health 10, 112. http://dx.doi.org/10.1186/1471-245810-112

Brink, H., Van der Walt, C. \& Van Rensburg, G., 2012, Fundamentals of research methodology for healthcare professionals, 3rd edn., Juta and Company, Cape Town.

Burns, N. \& Grove, S.K., 2001, The practice of nursing research: Conduct, critique, \& utilization, 4th edn., W.B Saunders Company, Philadelphia.

Capstick, T.G., Laycock, D. \& Lipman, M.C., 2011, 'Treatment interruptions and inconsistent supply of anti-tuberculosis drugs in the United Kingdom', The International Journal of Tuberculosis and Lung Disease 15(6), 754-760. http:// dx.doi.org/10.5588/ijtld.10.0568

Cramm, J.M., Finkenflügel, H.J.M., Møller, V. \& Nieboer, A.P., 2010, 'TB Treatment initiation and adherence in a South African community influenced more by perceptions than knowledge of tuberculosis', BMC Public Health 10, 72. http:// dx.doi.org/10.1186/1471-2458-10-72

Cresswell, J.W., 2003, Research design: Qualitative, quantitative, and mixed method approaches, 2nd edn., Sage Publications, Thousand Oaks, CA.

Demissie, M., Getahun, H. \& Lindtjørn, B., 2003, 'Community tuberculosis care through "TB clubs" in rural North Ethiopia', Social Science \& Medicine 56(10), 2009-2018. http://dx.doi.org/10.1016/S0277-9536(02)00182-X

Department of Health, 2009a, The national strategic health development plan framework (2009-2015), viewed 26 February 2014, from http://www. internationalhealthpartnership.net/fileadmin/uploads/ihp/Documents/Country Pages/Nigeria/Nigeria\%20National\%20Strategic\%20Health\%20Development\%20 Plan\%20Framework\%202009-2015.pdf

Department of Health, 2009b, National Tuberculosis Management Guidelines, viewed 23 February 2014, from http://familymedicine.ukzn.ac.za/Libraries/Guidelines Protocols/TB_Guidelines_2009.sflb.ashx

De Vos, A.S., 2005, Research at grass roots, for social sciences and human services profession, 3rd edn., Van Schaik Publishers, Pretoria.
Dimitrova, B., Balabanova, D., Atun, R., Drobniwinski, F., Levicheva V. \& Coker R., 2006 'Health service providers' perceptions of barriers to tuberculosis care in Russia', Health Policy and Planning 21(4), 265-274. http://dx.doi.org/10.1093/heapol/ czl014

Garrib, A., Stoops, N., McKhenzie, A., Dlamini, L., Govender, T., Rohde, J. et al., 2008, 'An evaluation of the District Health Information System in rural South Africa', South African Medical Journal 98(7), 549-552.

Gandhi, N.R., Moll, A., Sturm, A.W., Pawinski, R., Govender, T., Lalloo, U. et al., 2005, 'Extensively drug-resistant tuberculosis as a cause of death in patients co-infected with tuberculosis and HIV in a rural area of South Africa', The Lancet 368(9547), 1575-1580. http://dx.doi.org/10.1016/S0140-6736(06)69573-1

Hane, F., Thiam, S., Fall, A.S., Vidal, L., Diop, A.H., Ndir, M. et al., 2007, 'Identifying barriers to effective tuberculosis control in Senegal: an anthropological approach The International Journal of Tuberculosis and Lung Disease 11(5), 539-543.

Hassim, A., Heywood, M. \& Berger, J., 1998, 'Health research and ethical principles', in Health and Democracy, viewed 26 February 2014, from http://www.section27. org.za/wp-content/uploads/2010/04/Chapter12.pdf

Hoa, N.P., Thorson, A.E., Long, N.H. \& Diwan, V.K., 2003, 'Knowledge of tuberculosis and associated health-seeking behaviour among rural Vietnamese adults with a cough for at least three weeks', Scandinavian Journal for Public Health Supplement 62, 59-65. http://dx.doi.org/10.1080/14034950310015121

Kiwuwa, M.S., Karamagi, C. \& Mayanja, K.H., 2005, 'Patient and health service delay in pulmonary tuberculosis patients attending a referral hospital: A cross-sectional study', BMC Public Health 5, 122. http://dx.doi.org/10.1186/1471-2458-5-122

Mabunda, J. \& Bradley, H., 2011, 'Factors contributing to poor performance of Directly Observed Treatment Short-course (DOTS) in Mopani District, Limpopo Province, South Africa', African Journal for Physical, Health Education, Recreation and Dance Supplement 2(1), 93-107.

Polit, D.F. \& Beck, C.T., 2007, Nursing research: Generating and assessing evidence for nursing practice, 8th edn., Lippincott, Philadelphia.

Sagbakken, M., Frich, J.C. \& Bjune, G., 2008, 'Barriers and enablers in the management of tuberculosis treatment in Addis Ababa, Ethiopia: A qualitative study', BMC Public Health 8, 11. http://dx.doi.org/10.1186/1471-2458-8-11

Selig, L., Belo, M.T., Teixera, E.G., Cunha, A.J., Brito, R., Sanches K. et al., 2003, 'The study of tuberculosis-attributed deaths as a tool for disease control planning in Rio de Janeiro, Brazil', International Journal of Tuberculosis and Lung Disease 7(9), 855-859.

Sukumani, J., Lebese, R.T. \& Khoza, L.B., 2011, 'Challenges faced by family members while caring for TB patients at home', Africa Journal of Health Education, Recreation and Dance, supplement 2(1), 162-171.

Tang, S. \& Squire, S.B., 2005, 'What lessons can be drawn from tuberculosis (TB) control in China in the 1990s? An analysis from a health system perspective', Health Policy 72(1), 93-104. http://dx.doi.org/10.1016/j.healthpol.2004.06.009

Van der Werf, T.S., Dade G.K. \& Van der Mark, T.W., 1990, 'Patient compliance with tuberculosis treatment in Ghana: factors influencing adherence to therapy in a rural service programme', Tubercle 71(4), 247-252. http://dx.doi. therapy in a rural service programm
org/10.1016/0041-3879(90)90036-8

Walley, J.D., Khan, M.A., Newell, J.N. \& Khan, M.H., 2001, 'Effectiveness of the direct observation component of DOTS for tuberculosis: A randomised controlled trial in Pakistan', The Lancet 357(9257), 664-669. http://dx.doi.org/10.1016/S01406736(00)04129-5

Wares, D.F., Singh, S., Acharya, A.K. \& Dangi, R., 2003, 'Non-adherence to tuberculosis treatment in the eastern Tarai of Nepal', The International Journal of Tuberculosis and Lung Disease 7(4), 327-335.

World Health Organization, 2009, Global tuberculosis control - epidemiology, strategy, financing, WHO Report 2009, viewed 23 February 2014, from http://www.who. int/tb/publications/global_report/2009/en/

World Health Organization, 2010, Global tuberculosis control - WHO Report 2010 viewed 26 February 2014, from http://reliefweb.int/sites/reliefweb.int/files/ resources/F530290AD0279399C12577D8003E9D65-Full_Report.pdf

Zvavamwe, S. \& Ehlers, V.J., 2008, 'Implementing a community-based tuberculosis programme in the Omaheke region of Namibia: nurses' perceived challenges', Health SA Gesondheid 13(3), 54-68. http://dx.doi.org/10.4102/hsag.v13i3.286 